\title{
STUDY OF LIMNOLOGICAL STATUS OF KUNGHADABANDH LAKE AND CHAMORSHI LAKE, DIST. - GADCHIROLI (M. S.)
}

\author{
Rajendra V. Tijare $^{1}$ and Gurudeo E. Kunghadkar ${ }^{2}$
}

1. Institute of Science, R.T. Road civil Lines, Nagpur, 440001.

2. Government Medical College, Chandrapur, 442402.

Corresponding address: rutijare@gmail.com

\begin{abstract}
:
The water samples for physico-chemical parameters were collected from Kunghadabandh Lake and Chamorshi Lake, Tah. Chamorshi, Dist. Gadchiroli covers five stations East, West, North, South and Centre. The collected water samples in a plastic can from each station were immediately analysed in the laboratory. Some parameters were analysed on the sampling sites by using titrimetric mobile test water kit and digital pen meter. The samples were collected monthly for the period of 2 years (February 2012 to January 2014). Samples were mostly collected during morning hours i.e. in between 8 am to $10 \mathrm{am}$ and analysed in the same day in laboratory to avoid any type of error. Various physico-chemical parameters play an important role in water quality as well as diversity and richness of organisms. Mostly temperature is a very important factor. Others factors like $\mathrm{pH}$, Dissolved oxygen, free CO2, Suspended solids, etc. also affect the frequency of organisms.
\end{abstract}

Key words: - As Physico-chemical, Parameter, Kunghadabandh, Chamorshi.

\section{INTRODUCTION:}

Limnology is closely related with hydrobiology and aquatic ecology in which aquatic organisms particularly regard their hydrological environment (Cole, 1994). Limnologists are working very hard to maintain the quality and quantity of water, especially fresh water because of its great importance to human beings and other living things to maintain the food chain and food web consequently ecosystem. The physical, chemical and biological factors are responsible for determination of quality of water.

The two perennial water bodies of Gadchiroli district i.e. Kunghdabandh and Chamorshi lakes are taken into consideration for analyzing the different physicochemical parameters.

\section{1) Kunghadabandh Lake $\left(20.22^{\circ} \mathrm{N}-80.01^{\circ} \mathrm{E}\right.$.):}

Kunghadabandh was constructed by British Government in 1890. It is situated in the eastern part of Maharashtra, 20 kilometre away from
Gadchiroli District place. This lake comes under the supervision of the Irrigation department of Chamorshi Taluka, District Gadchiroli. Total area of the lake is 5.95 sq. $\mathrm{km}$. water occupying and having 3.017 cubic density while the useful water storage is of about 2.844 cubic density. The total area is about 34.70 hectare and perimeter is 1372 meter. The water is mostly used for irrigation and fishing purposes. As the lake is far away from urban areas so anthropogenic activities were very less.

\section{2)Chamorshi Lake $\left(19.55^{\circ} \mathrm{N}-7_{9.52}^{\circ} \mathrm{E}\right.$.):}

Chamorshi Lake is also known as "Gav Talao" and is situated in the centre of Chamorshi city. It is 35 kilometer away from the Gadchiroli District and $15 \mathrm{~km}$ from the Kunghadbandh. It is relatively a small lake as compared to Kunghadabandh. It has a perimeter of 1260 meter. The total area of this lake is 21.15 hectare. The water is used for domestic purposes. Near about $50 \%$ of the area of this lake is covered by vegetation. 


\section{MATERIAL \& METHODS}

The water samples were collected in a plastic can from each sampling station and immediately analyzed in the laboratory. Some parameters were analyzed on the spot such as temperature, $\mathrm{pH}$, dissolved oxygen, etc. by using titrimetric mobile test water kit and digital pen meter. The samples were collected monthly for the period of 2 years (February 2012 to January 2014) and categorized them according to their seasons i.e. February to May-Summer, June to SeptemberMonsoon and October to January-Winter. Samples were mostly collected during 08 am to $10 \mathrm{am}$. and analyzed on the same day to avoid any error.

During the monitoring of samples, various parameters and factors were taken into consideration and categorized them mainly into three types:

i) Physical parameter: Such as Temperature, $\mathrm{pH}$, Total solids, Total dissolved solids, Suspended solids, Turbidity and Electrical conductivity.

ii) Chemical parameter: such as Total hardness, Calcium hardness, Magnesium hardness, Calcium ion, Magnesium ion, Dissolved Oxygen, free Carbon Dioxide, Alkalinity, Acidity, Phosphate, Nitrate, Sulphate and Chloride.

The analyses of all collected samples were done as per available and prescribed standard methods such as AWA-APHA (1985, 2010), Trivedi and Goel (1984) and Santhanam et al. (1989).

\section{RESULT \& DISCUSSION}

The monthly, seasonal and annual values of Physico-chemical parameters (Temperature to Chloride) are illustrated in Table No. 1 to 4 .

1) Water Temperature $\left({ }^{\circ} \mathrm{C}\right)$ : In Kunghadabandh Lake, the minimum average of temperature $(22.38 \pm 0.92)$ was recorded in winter and maximum average of temperature $(25.98 \pm 1.56)$ in summer as compared to the annual average of temperature $(24.73 \pm 2.03)$. In Chamorshi Lake, the minimum average temperature $(26.74 \pm 1.84)$ was recorded in winter and maximum average temperature (29.98 \pm 1.85 ) in summer as compared to the annual average of temperature (28.82 \pm 2.15 ). Temperature mostly increases during summer and declines during winter because atmospheric temperatures are highest in summer and winter have lowest (Rajanna and Belagali, 2011 and Dubey et. al., 2013). The high temperatures were recorded in summer while lower in winter.

2) pH: In Kunghadabandh Lake, minimum average of $\mathrm{pH}(7.67 \pm 0.17)$ was recorded in monsoon and maximum average of $\mathrm{pH}$ $(8.11 \pm 0.11)$ in summer as compared to the annual average of $\mathrm{pH}(7.94 \pm 0.65)$. In Chamorshi Lake, the minimum average of $\mathrm{pH}(7.48 \pm 0.08)$ was recorded in summer and maximum average of $\mathrm{pH}(8.17 \pm 0.04)$ in winter as compared to the annual average of $\mathrm{pH}(7.8 \pm 0.3)$. It might be due to the when photosynthesis uses up dissolved $\mathrm{CO}_{2}$, which acts like carbonic acid. Carbon dioxide removal, in effect, reduces the $\mathrm{pH}$ of water (Webber and Stumm, 1963 and Shastri et. al., 1991). In summer pH was less than monsoon and winter. Kunghadabandh Lake has high $\mathrm{pH}$ values as compared to the Chamorshi Lake, due to less vegetation, dead and debris material and less respirationdecomposition rate in water.

3) Total Solids (TS-mg/lit): In Kunghadabandh Lake, minimum average of total solids $(78.25 \pm 4.49)$ was recorded in winter and maximum average of total solids (102.25 \pm 6.27$)$ in summer as compared to the annual average of total solids (93.42 \pm 12.92$)$. In Chamorshi Lake, minimum average of total solids $(133 \pm 5.82)$ 
was recorded in winter and maximum average of total solids $(154.87 \pm 3.07)$ in summer as compared to the annual average of total solids (145.20 \pm 10.69$)$. Total solids mostly increase during summer due to increases in sedimentation and decrease in quantity of water which results in decrease in depth of water also (Sluiter et. al., 2008). Total solids observed in Kunghadabandh Lake were less than Chamorshi Lake during the investigation period.

4) Total Dissolved Solids-(TDS-mg/lit): In Kunghadabandh Lake, minimum average of total dissolved solids (60.88 \pm 4.88$)$ was recorded in winter and maximum average of total dissolved solids $(81.5 \pm 5.18)$ in summer as compared to the annual average of total dissolved solids (74.21 11.21$)$. In Chamorshi Lake, minimum average of total dissolved solids $(118 \pm 5.51)$ was recorded in winter and maximum average of total dissolved solids $(135 \pm 2.26)$ in summer as compared to the annual average of total dissolved solids

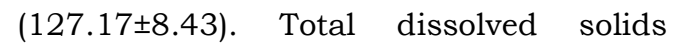
mostly increase during summer due to increases in sedimentation and decrease in quantity of water which results in decrease in depth of water also (Sluiter et. al., 2008). Total dissolved solids were observed less in winter than summer. Kunghadabandh Lake has lower values of total dissolved solids than Chamorshi Lake, due to organic and inorganic inputs.

\section{5) Suspended Solids (mg/lit): In}

Kunghadabandh Lake, minimum average of suspended solids $(17.37 \pm 1.56)$ was recorded in winter and maximum average of suspended solids $(20.75 \pm 1.44)$ in summer as compared to the annual average of suspended solids (19.20 \pm 2.08$)$. In Chamorshi Lake, minimum average of suspended solids $(15 \pm 0.93)$ was recorded in winter and maximum average of suspended solids $(19.87 \pm 1.47)$ in summer as compared to the annual average of suspended solids (18.04 \pm 2.88$)$. Suspended solids mostly increase during summer due to decrease in quantity of water which results in decrease in depth of water also (Wilson, 2010). The suspended solids were found less in winter than summer. Kunghadabandh Lake has slightly high values of suspended solids as compared to the Chamorshi Lake, as it occurs might be due to seasonal fluctuation and interference of domestic animals in water during analysis.

6) Turbidity (NTU): In Kunghadabandh Lake, the minimum average of turbidity $(6.3 \pm 0.25)$ was recorded in winter and maximum average of turbidity $(7.32 \pm 0.22)$ in monsoon as compared to the annual average of turbidity (6.78 \pm 0.49$)$. In Chamorshi Lake, the minimum average of turbidity $(8.29 \pm 0.22)$ was recorded in winter and maximum average of turbidity $(9.42 \pm 0.38)$ in summer as compared to the annual average of turbidity $(8.95 \pm 0.65)$. Turbidity mostly increases during summer due to decreases in depth of water and in monsoon also due to surface run-off while decreases in winter due to increase in depth of water and water is mostly constant in winter (Sluiter et. al., 2008). Less turbidity was noticed in winter due to settling effect than summer and monsoon. Kunghadabandh Lake has low turbidity as compared to the Chamorshi Lake.

7) Electrical Conductivity ( $\mu \mathrm{mhos} / \mathrm{cm}$ ): In Kunghadabandh Lake, minimum average of electrical conductivity $(95 \pm 5.43)$ was recorded in winter and maximum average of electrical conductivity (114.37 \pm 9.81$)$ in summer as compared to the annual 
average of electrical conductivity (107.46 \pm 11.29$)$. In Chamorshi Lake, minimum average of electrical conductivity (206.62 \pm 7.8$)$ was recorded in winter and maximum average of electrical conductivity (256.75 \pm 15.02$)$ in summer as compared to the annual average of electrical conductivity (237.92 \pm 27.81$)$. Conductivity mostly increases during summer because of surface evaporation of water which results in rising of concentration of salts while decline in conductivity during in winter is due to the sedimentation and utilization of minerals by growing phytoplankton and macrophytes (Puri et. al., 2010). The electrical conductivity was mostly decline in winter and increased in summer. Kunghadabandh Lake has low values of electrical conductivity as compared to the Chamorshi Lake, as it occurs might be due to less sedimentation and less concentration of salts in water than Chamorshi Lake.

8) Total Hardness (mg/lit): In Kunghadabandh Lake, minimum average of total hardness $(63.16 \pm 2.96)$ was recorded in winter and maximum average of total hardness $(86.95 \pm 3.57)$ in summer as compared to the annual average of total hardness (76.02 \pm 10.91$)$. In Chamorshi Lake, minimum average of total hardness (251.87 \pm 5.41$)$ was recorded in winter and maximum average of total hardness $(289.37 \pm 12.15)$ in summer as compared to the annual average of total hardness (266.58 \pm 18.21$)$. It occurs might be due to high temperature in summer which results in the breakdown of rocks, less amount of water and domestic uses specially detergents (Sukund and Patil, 2004). Total hardness was mostly decline in winter and increases in summer. Kunghadabandh
Lake has low values of total hardness as compared to the Chamorshi lake, might be due less anthropogenic activities occurred.

9) Calcium Hardness (mg/lit): The minimum average of calcium hardness $(31.32 \pm 0.99)$ of Kunghadabandh Lake was recorded in winter and maximum average of calcium hardness (41.72 \pm 5.53$)$ in summer as compared to the annual average of calcium hardness (37.08 \pm 5.69$)$. In Chamorshi Lake minimum average of calcium hardness

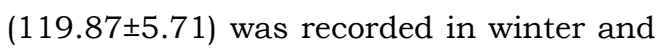
maximum average of calcium hardness $(144.25 \pm 7.07)$ in summer as compared to the annual average of calcium hardness (131.71 \pm 11.56$)$. (Karim et. al. 2012). The calcium hardness was mostly declines in winter and increases in summer. Kunghadabandh Lake has low values of calcium hardness as compared to the Chamorshi Lake, as it occurs might be due to Kunghadabandh Lake having good quantity, quality of water and less domestic uses than Chamorshi Lake.

10) Magnesium Hardness (mg/lit): In Kunghadabandh Lake minimum average of magnesium hardness (31.35 \pm 2.17$)$ was recorded in winter and maximum average of magnesium hardness (45.22 \pm 5.23$)$ in summer as compared to the annual average of magnesium hardness (38.78 \pm 7.29$)$.In Chamorshi Lake minimum average of magnesium hardness $(126.25 \pm 1.15)$ was recorded in winter and maximum average of magnesium hardness $(145 \pm 5.18)$ in summer as compared to the annual average of magnesium hardness (134.46 \pm 8.65$)$. It might be due to the degradation of plants in summer and most of the magnesium is utilized by large vegetation in monsoon and winter (Shinde et. al., 2010). Magnesium hardness was found to be less in winter than in summer. 
Kunghadabandh Lake has low values of magnesium hardness as compared to the Chamorshi Lake, probably less algal bloom and anthropogenic activities.

11) Calcium-Ca ${ }^{++}$(mg/lit): The minimum average value of $\mathrm{Ca}^{++}(12.72 \pm 0.48)$ was recorded in winter and maximum average of $\mathrm{Ca}^{++}(16.69 \pm 2.21)$ in summer as compared to the annual average of $\mathrm{Ca}^{++}$ (14.90 \pm 2.22$)$ of Kunghadabandh Lake while in Chamorshi Lake minimum average of $\mathrm{Ca}^{++}(47.95 \pm 2.29)$ was recorded in winter and maximum average of $\mathrm{Ca}^{++}$ $(57.7 \pm 2.83)$ in summer as compared to the annual average of $\mathrm{Ca}^{++}(52.68 \pm 4.62)$.

12) Magnesium- $\mathbf{M g}^{++} \quad$ (mg/lit): In Kunghadabandh Lake minimum average of $\mathrm{Mg}^{++}(7.52 \pm 0.52)$ was recorded in winter and maximum average of $\mathrm{Mg}^{++}(10.85 \pm 1.26)$ in summer as compared to the annual average of $\mathrm{Mg}^{++}(9.31 \pm 1.75)$. In Chamorshi Lake minimum average of $\mathrm{Mg}^{++}(30.3 \pm 0.27$ was recorded in monsoon and maximum average of $\mathrm{Mg}^{++}(64.83 \pm 1.24)$ in summer as compared to the annual average of $\mathrm{Mg}^{++}(32.27 \pm 2.08)$. It might be due to the degradation of plants, more leaching of rocks in summer and most of the magnesium is utilized by large vegetation in monsoon and winter (Pawar and Sonawane, 2011).

13) Dissolved Oxygen (mg/lit): Minimum average value of dissolved oxygen $(5.71 \pm 0.1)$ was recorded in summer and maximum average of dissolved oxygen $(6.41 \pm 0.29)$ in monsoon as compared to the annual average of dissolved oxygen (5.47 \pm 0.48$)$ from Kunghadabandh Lake. In Chamorshi Lake minimum average of dissolved oxygen (4.69 \pm 0.15$)$ was recorded in summer and maximum average of dissolved oxygen $(5.14 \pm 0.05)$ in winter as compared to the annual average of dissolved Oxygen (4.95 \pm 0.26$)$. It occurs due to low temperature in monsoon and winter as if water is too warm (summer), there may not be enough dissolved oxygen in it (Zutshi and Vaas, 1978, Prasad and Manjula, 1980). Dissolved oxygen mostly declines in summer and increases in monsoon and winter. While Kunghadabandh Lake has more dissolved oxygen observed as compared to the Chamorshi Lake, it might be due to the fair quality of water.

14) Free $\mathrm{CO}_{2}$ (mg/lit): In Kunghadabandh Lake minimum average of Free $\mathrm{CO}_{2}$ $(5.04 \pm 0.22)$ was recorded in winter and maximum average of free $\mathrm{CO}_{2}(6.12 \pm 0.31)$ in summer as compared to the annual average of free $\mathrm{CO}_{2} \quad(5.58 \pm 0.52)$. In Chamorshi Lake minimum average of free $\mathrm{CO}_{2}(10.59 \pm 0.39)$ was recorded in winter and maximum average of free $\mathrm{CO}_{2}$ $(19.17 \pm 1.75)$ in summer as compared to the annual average of free $\mathrm{CO}_{2}$

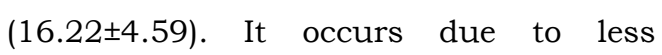
temperature in winter as if water is too warm (summer), there may be high free $\mathrm{CO}_{2}$ in it (Kaushik and Saksena, 1991). The free CO2 was mostly declines in winter and increases in summer. Chamorshi Lake has more free $\mathrm{CO}_{2}$ as compared to the Kunghadabandh Lake.

15) Alkalinity (mg/lit): In Kunghadabandh Lake minimum average of alkalinity $(58.56 \pm 0.80)$ was recorded in winter and maximum average of alkalinity $(72.66 \pm 2.92)$ in summer as compared to the annual average of alkalinity (67.15 \pm 6.86$)$. In Chamorshi Lake minimum average of alkalinity

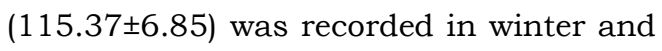
maximum average of alkalinity $(143.37 \pm 3.83)$ in summer as compared to the annual average of alkalinity 
(132.79 \pm 14.24$)$. It might be due to the photosynthesis as carbon dioxide removes, in effect increases the alkalinity of water especially in summer. Alkalinity was mostly declines in winter and increases in summer. Kunghadabandh Lake has low values of alkalinity as compared to the Chamorshi Lake, due to less turbidity and TDS in water than Chamorshi Lake.

16) Acidity (mg/lit): In Kunghadabandh Lake minimum average of acidity (3.7 \pm 0.22$)$ was recorded in winter and maximum average of acidity $(5.16 \pm 0.35)$ in summer as compared to the annual average of acidity (4.38 \pm 0.65$)$. In Chamorshi Lake minimum average of acidity $(7.76 \pm 0.48)$ was recorded in monsoon and maximum average of acidity (9.17 \pm 0.26$)$ in summer as compared to the annual average of acidity (8.39 \pm 0.74$)$. It might be due to when photosynthesis uses up dissolved $\mathrm{CO}_{2}$, which acts like carbonic acid. Carbon dioxide removal, in effect, reduces the acidity of water.

17) Phosphate (mg/lit): In Kunghadabandh Lake minimum average of phosphate $(0.11 \pm 0.04)$ was recorded in winter and maximum average of phosphate $(1.14 \pm 0.69)$ in monsoon as compared to the annual average of phosphate $(0.71 \pm 0.59)$. In Chamorshi Lake minimum average of phosphate $(0.55 \pm 0.51)$ was recorded in winter and maximum average of phosphate $(3.02 \pm 0.48)$ in monsoon as compared to the annual average of phosphate (1.99 \pm 1.15$)$. Phosphate mostly increases during monsoon due to increase in algal bloom and surface run-off while decreases in summer due to decrease in algal bloom and less vegetation in water (Welch, 1952). Phosphate recorded in summer was less than in monsoon. Chamorshi Lake has more phosphate than
Kunghadabandh Lake due to heavy inputs of domestic wastes.

18) Nitrate (mg/lit): In Kunghadabandh Lake minimum average of nitrate $(0.36, \pm 0.13)$ was recorded in summer and maximum average of nitrate $(0.94, \pm 0.16)$ in monsoon as compared to the annual average of nitrate $(0.61, \pm 0.33)$. In Chamorshi Lake minimum average of nitrate $(0.46, \pm 0.15)$ was recorded in summer and maximum average of nitrate $(1.17, \pm 0.17)$ in monsoon as compared to the annual average of nitrate $(0.72, \pm 0.39)$. Nitrate mostly increases during monsoon due to increase in vegetation and surface run-off which include fertilizers while decreases in summer due to decrease in vegetation and surface run-off in water (Pande et. al. 1969, Chatwal, 1996 and Das, 1989). In all nitrate values found to be the minimum in summer and more in monsoon. Nitrates of Kunghadabandh Lake have calculated low as compared to the Chamorshi Lake.

19) Sulphate (mg/lit): In Kunghadabandh Lake minimum average of sulphate $(17.24 \pm 0.41)$ was recorded in summer and maximum average of sulphate $(21.54 \pm 1.51)$ in monsoon as compared to the annual average of sulphate (19.84 \pm 2.23$)$. In Chamorshi Lake minimum average of sulphate (32.22 \pm 1.21$)$ was recorded in winter and maximum average of sulphate $(41.05 \pm 1.03)$ in monsoon as compared to the annual average of sulphate (37.56 \pm 4.31$)$. Sulphate mostly increases during monsoon due to surface run-off which include fertilizers while decreases in summer due to decrease in surface run-off in water (Kaur et. al., 1995 and Kemp et. al., 1972). Low values of sulphate found to be less in Kunghadabandh Lake than Chamorshi Lake. 
20) Chloride (mg/lit): Minimum average value of chloride $(4.77 \pm 0.31)$ was recorded in summer and maximum average of chloride (6.57 \pm 0.4$)$ in monsoon from Kunghadabandh Lake as compared to the annual average of chloride (5.92 \pm 0.9$)$. In Chamorshi Lake minimum average of chloride (7.07 \pm 0.61$)$ was recorded in summer and maximum average of chloride $(9.62 \pm 0.22)$ in winter as compared to the annual average of chloride $(8.19 \pm 1.18)$. Chloride mostly increases during monsoon or in winter due to surface run-off. Accumulation of Chlorides in water is due to the dissolution of salts from rock and soils. Chloride was found to be higher in summer than in monsoon and winter. Chamorshi Lake has high chloride due to inputs of excessive domestic wastes in lake water than Kunghadabandh Lake.

\section{CONCLUSION}

The physico-chemical parameters play an important role in water quality as well as it affects on the diversity and richness of organisms. After calculating various physicochemical parameters of both the lakes, the limnological status and water quality of Kunghadabandh Lake was found to be fair as compared to water of Chamorshi Lake.

\section{REFERENCES}

AWWA-APHA (1985): Standard methods for the examination of water and wastewater. $16^{\text {th }}$ ed. American Public Health Association. Washington, E.U.A.

AWWA-APHA (2010): Standard methods for the examination of water and wastewater. $21^{\text {st }}$ Ed. American Public Health Association. Washington, D. C.

Chatwal, G. R. (1996): Encyclopedia of Environmental Pollution, volume 1,
Anmol Publications Pvt. Ltd. New Delhi, India.

Cole, G. A. (1994): Textbook of Limnology, 4th ed.Wavelard press, ISBNO-88133-8001.

Das, A. K. (1989): Handbook of limnology and water pollution with practical methodology. South Asian publishers. Rt. Ltd. New Delhi. pp. 174.

Dubey M., A. K. Tiari and N. C. Ujjaina (2013): The study of Physico-chemical properties of Shahapur Lake Bhopal (I), International Journal of Advanced Research. Volume (1), Issue (8), 158164.

Karim L. R., M. S. V.Nair and E. S. Williams (2012): Municipal Solid Waste dumping on Ashtamudi lake, Kollam, Kerala - An overview, The Ecoscan. Volume 1: 105-110.

Kaur K., K. Vijaykumar and D.Holkar (1995):Limnological studies on Chandramalli reservoir, Gulbarga. Freshwater Ecosystem of India. Daya Publishing House, Delhi.

Kaushik, S. and D. N. Saksena (1991):Physicochemical factors and the aquatic insect density of a pond receiving cotton mill effluent at Gwalior. Indian Journal of Ecology, 16 (1): 64-67.

Kemp A. L. W., C. B. J. Gray and A. Mudrochova (1972): Changes in C, N, P and S in the last 140 years in three cores from lakes Ontario, Erie and Huron. 251279. J. Wiley and Sons, New York.

Pande, P. C., K. Suryanarayana and G. G. Deshpande (1969): Seasonal changes in physical and chemical conditions of some Indian Lake. Mineral research.Vol.2,pp20-28.

Pawar, S. and S. Sonawane (2011): Water quality index of Kanher Dam of Satara District 
(M. S.) India. Int. Journal of Biosciences. Vol. 1(6): 81-87.

Puri P. J., M. K. N. Yenkie, D. G. Battalwar, N. V. Gandhare and D. B. Dhanorkar (2010): Study and interpretation of physicochemical characteristic of lake water quality in Nagpur city (India). Rasayan Journal of Chem. Volume 3, No. 4. Pg. 800-810 ISSN: 0974-1496.

Prasad, B. N. and S. Manjula (1980): Ecological study of Blue green algae in river Gomati. Indian Journal of Environmental Health, 22: 151-168.

Rajanna, A. H. and S. L. Belagali (2011): Assessment of Seasonal Variation Of Physico chemical Profile of Kabini River, Nanjangud, Mysore, Karnataka. The Ecoscan, 5 (3 \& 4): pp. 147:151.

Santhanam R., P. Velayutham and G. Jegatheesan (1989): A manual of freshwater ecology. Anil Mittal for Daya Publishing House, Delhi.ISBN 817035-054-9.

Shastri, N. K., M. S. Islam, Pathak and M. Afsan (1991): Studies on the physicochemical dimensions of the lentic hydrosphere of RavindraSarovar (Gaya). In: Current Trends in Limnology. Volume-I. Narendra Publishing House, Delhi, pp: 133-152.

Shinde S. K., T. S. Pathan., K. S. Raut., P. R. More and D. L. Sonawane (2010): Seasonal variation in Harsul Sawangi Dam, District Aurangabad, India. The Ecoscan. 4(1): 37-44.

Sluiter, A., B. Hames, R. Ruiz, C. Scarlata, J. Sluiter and D. Templeton (2008): Determination of structural carbohydrates and lignin in biomass. LAP-002 NREL Analytical Procedure. National Renewable Energy Laboratory, Golden, CO.

Sukund, B. N. and H. S.Patil (2004): Water quality assessment for lake of Belgaum (Karnataka) with special reference to zooplankton, Journal of Environmental Biology. 25(1): 99-102.

Trivedi, R. K. and P. K. Goel (1984): Chemical and biological methods for water pollution studies. Karad Environmental publication, pp: 1-251.

Webber, W. J. and Stumm (1963): Mechanism of Hydrogen ion buffering in natural waters. Journal of American Water Works Association. 155: 1553.

Welch, P. S. (1952): Limnology. Mc. Graw Hill book Company, New York.

Wilson, P. C. (2010): Water Quality Notes: Water Clarity (Turbidity, Suspended Solids, and Color). University of Florida IFAS Extension-SL314.

Zutshi, D. P. and K. K. Vass (1978):Limnological studies on Dal Lake. Chemical features, Indian Journal of Ecology. 5: 90-97. 
Table 1: Monthly and seasonal Physico-chemical readings of Kunghadabandh Lake during February 2012 to January 2013.

\begin{tabular}{|c|c|c|c|c|c|c|c|c|c|c|c|c|c|c|}
\hline S.N & Parameters & Unit & Sumn & & & & Mons & & & & Wint & & & \\
\hline & & & FEB & MAR & $\overline{\text { APR }}$ & MAY & JUN & JUL & AUG & SEP & OCT & $\mathrm{NOV}$ & DEC & JAN \\
\hline 01 & Water Temperature & ${ }^{\circ} \mathrm{C}$ & 24 & 25.2 & 26.5 & 28.2 & 27.1 & 26.1 & 25.5 & 24.6 & $\begin{array}{l}23.8 \\
5\end{array}$ & 22.5 & 21.5 & 21.7 \\
\hline 02 & $\mathbf{P h}$ & $\ldots \ldots \ldots$ & 8 & 8 & 8.25 & 8.2 & 7.9 & 7.75 & 7.45 & 7.6 & 7.95 & 8.3 & 7.9 & 7.95 \\
\hline 03 & Total Solids & $\underset{\mathrm{t}}{\mathrm{mg} / \mathrm{li}}$ & 97 & 96.5 & $\begin{array}{l}103 . \\
5\end{array}$ & 112 & 116 & 98 & 93.5 & 91.5 & 83 & 82 & 76 & 72 \\
\hline 04 & TDS & $\begin{array}{l}\mathrm{mg} / \mathrm{li} \\
\mathrm{t}\end{array}$ & 76 & 78 & 82.5 & 89.5 & 94 & 79 & 74 & 74 & 66 & 65.5 & 56 & 56 \\
\hline 05 & Suspended Solids & $\begin{array}{l}\mathrm{mg} / \mathrm{li} \\
\mathrm{t}\end{array}$ & 21 & 18.5 & 21 & 22.5 & 22 & 19 & 19.5 & 17.5 & 17 & 16.5 & 20 & 16 \\
\hline 06 & Turbidity & NTU & 6.45 & 6.6 & 6.7 & 7.15 & 7.2 & 7.65 & 7.4 & 7.05 & 6.7 & 6.3 & 6.15 & 6.05 \\
\hline 07 & $\begin{array}{l}\text { Electrical } \\
\text { Conductivity }\end{array}$ & $\begin{array}{l}\mu \mathrm{mho} \\
\mathrm{s} / \mathrm{cm}\end{array}$ & 102 & 110.5 & 116 & 129 & $\begin{array}{l}120 . \\
5\end{array}$ & 113.5 & $\begin{array}{l}110 . \\
5\end{array}$ & 107.5 & 103 & 96 & 88 & 93 \\
\hline 08 & Total Hardness & $\begin{array}{l}\mathrm{mg} / \mathrm{li} \\
\mathrm{t}\end{array}$ & $\begin{array}{l}81.8 \\
5\end{array}$ & 85.65 & $\begin{array}{l}88.9 \\
5\end{array}$ & 91.35 & 86.5 & 81.4 & 76 & 67.95 & 63.9 & 60.6 & $\begin{array}{l}60.4 \\
5\end{array}$ & 67.7 \\
\hline 09 & Calcium Hardness & $\begin{array}{l}\mathrm{mg} / \mathrm{li} \\
\mathrm{t}\end{array}$ & $\begin{array}{l}38.5 \\
5\end{array}$ & 44.35 & $\begin{array}{l}34.7 \\
5\end{array}$ & 49.25 & 38 & 41.2 & 40.4 & 33.15 & 32.5 & 31.9 & $\begin{array}{l}29.8 \\
5\end{array}$ & 31.05 \\
\hline 10 & Mg Hardness & $\begin{array}{l}\mathrm{mg} / \mathrm{li} \\
\mathrm{t}\end{array}$ & 43.3 & 41.3 & 54.2 & 42.1 & 48.5 & 40.2 & 35.6 & 34.8 & 31.4 & 28.7 & 30.6 & 34.7 \\
\hline 11 & Calcium- $\left(\mathbf{C a}^{++}\right)$ & $\begin{array}{l}\mathrm{mg} / \mathrm{li} \\
\mathrm{t}\end{array}$ & $\begin{array}{l}15.4 \\
2\end{array}$ & 17.74 & 13.9 & 19.7 & 15.2 & 16.48 & $\begin{array}{l}16.1 \\
6\end{array}$ & 13.26 & 13 & 12.76 & $\begin{array}{l}11.9 \\
4\end{array}$ & 13.2 \\
\hline 12 & Magnesium-( $\left.\mathbf{M g}^{++}\right)$ & $\begin{array}{l}\mathrm{mg} / \mathrm{li} \\
\mathrm{t}\end{array}$ & $\begin{array}{l}10.3 \\
9\end{array}$ & 9.91 & $\begin{array}{l}13.0 \\
1\end{array}$ & 10.1 & $\begin{array}{l}11.6 \\
4\end{array}$ & 9.65 & 8.54 & 8.35 & 7.54 & 6.89 & 7.34 & 8.33 \\
\hline 13 & Dissolved Oxygen & $\begin{array}{l}\mathrm{mg} / \mathrm{li} \\
\mathrm{t}\end{array}$ & 5.7 & 5.8 & 5.8 & 5.55 & 6 & 6.3 & 6.55 & 6.8 & 6.4 & 6.55 & 5.95 & 5.85 \\
\hline 14 & Free $\mathrm{CO}_{2}$ & $\begin{array}{l}\mathrm{mg} / \mathrm{li} \\
\mathrm{t}\end{array}$ & 5.8 & 5.9 & 6.2 & 6.6 & 6.05 & 5.6 & 5.5 & 5.2 & 5.3 & 5.2 & 4.75 & 4.9 \\
\hline 15 & Alkalinity & $\begin{array}{l}\mathrm{mg} / \mathrm{li} \\
\mathrm{t}\end{array}$ & 68.1 & 72.35 & $\begin{array}{l}74.2 \\
5\end{array}$ & 75.95 & 76.3 & 71.6 & $\begin{array}{l}68.3 \\
5\end{array}$ & 64.65 & $\begin{array}{l}58.9 \\
5\end{array}$ & 58.65 & $\begin{array}{l}57.2 \\
5\end{array}$ & 59.4 \\
\hline 16 & Acidity & $\begin{array}{l}\mathrm{mg} / \mathrm{li} \\
\mathrm{t}\end{array}$ & 5.65 & 5.3 & 5 & 4.7 & 4.5 & 4.25 & 4.3 & 4.05 & 3.8 & 3.6 & 3.4 & 4 \\
\hline 17 & Phosphate & $\begin{array}{l}\mathrm{mg} / \mathrm{li} \\
\mathrm{t}\end{array}$ & 0.68 & 0.79 & 0.92 & 1.09 & 1.92 & 1.41 & 1.13 & 0.09 & 0.07 & 0.12 & $\begin{array}{l}0.08 \\
5\end{array}$ & 0.17 \\
\hline 18 & Nitrate & $\begin{array}{l}\mathrm{mg} / \mathrm{li} \\
\mathrm{t}\end{array}$ & 0.21 & 0.285 & 0.39 & 0.56 & 0.68 & 0.98 & 0.98 & 1.11 & 1.04 & 0.64 & 0.22 & 0.25 \\
\hline 19 & Sulphate & $\begin{array}{l}\mathrm{mg} / \mathrm{li} \\
\mathrm{t}\end{array}$ & $\begin{array}{l}18.7 \\
5\end{array}$ & 20.1 & $\begin{array}{l}21.7 \\
5\end{array}$ & 22.4 & 22.8 & 23.1 & $\begin{array}{l}20.8 \\
5\end{array}$ & 19.4 & 17.8 & 17.15 & $\begin{array}{l}16.6 \\
5\end{array}$ & 17.35 \\
\hline 20 & Chloride & $\mathrm{mg} / \mathrm{li}$ & 4.7 & 4.5 & 4.6 & 5.3 & 5.9 & 6.7 & 6.8 & 6.9 & 7.1 & 6.35 & 6 & 6.25 \\
\hline
\end{tabular}


I J R B A T, Issue (VIII), Vol. I, Jan 2020: 174-185

A Double-Blind Peer Reviewed Journal
OPEN
e-ISSN 2347 - 517X

Original Article

Table 2: Monthly and seasonal Physico-chemical readings of Kunghadabandh Lake during February 2013 to January 2014.

\begin{tabular}{|c|c|c|c|c|c|c|c|c|c|c|c|c|}
\hline S.N & Parameters & Unit & Annual & Annual & Annual & Annual & $\begin{array}{l}\text { Summe } \\
\mathbf{r}\end{array}$ & $\begin{array}{l}\text { Summe } \\
\mathbf{r}\end{array}$ & $\begin{array}{l}\text { Monsoo } \\
\mathrm{n}\end{array}$ & $\begin{array}{l}\text { Monsoo } \\
\mathrm{n}\end{array}$ & Winter & Winter \\
\hline & & & Min & Max & Avg. & $\mathrm{SD}$ & Avg. & SD & Avg. & SD & Avg. & SD \\
\hline 01 & Water Temperature & ${ }^{\circ} \mathrm{C}$ & 20.8 & 27.5 & 23.91 & 2.10 & 25.32 & 1.51 & 25 & 1.16 & 21.42 & 0.55 \\
\hline 02 & pH & $\ldots \ldots \ldots$ & 7.5 & 8.3 & 7.89 & 0.21 & 8.02 & 0.08 & 7.72 & 0.14 & 7.92 & 0.24 \\
\hline 03 & Total Solids & $\begin{array}{l}\mathrm{mg} / \mathrm{li} \\
\mathrm{t}\end{array}$ & 70 & 101 & 87.66 & 9.68 & 94.75 & 4.65 & 92.7 & 4.54 & 75.5 & 3.84 \\
\hline 04 & TDS & $\begin{array}{l}\mathrm{mg} / \mathrm{li} \\
\mathrm{t}\end{array}$ & 54 & 79 & 70.08 & 8.16 & 75 & 3.39 & 75.5 & 2.29 & 59.75 & 4.81 \\
\hline 05 & Suspended Solids & $\mathrm{mg} / \mathrm{li}$ & 14 & 22 & 17.58 & 2.43 & 19.75 & 1.47 & 17.25 & 2.27 & 15.75 & 1.47 \\
\hline 06 & Turbidity & NTU & 5.9 & 7.6 & 6.79 & 0.50 & 6.82 & 0.37 & 7.25 & 0.22 & 6.3 & 0.33 \\
\hline 07 & $\begin{array}{l}\text { Electrical } \\
\text { Conductivity }\end{array}$ & $\begin{array}{l}\mu \mathrm{mho} \\
\mathrm{s} / \mathrm{cm}\end{array}$ & 84 & 123 & 102.16 & 11.19 & 106.25 & 11.69 & 108.25 & 5.97 & 92 & 6.81 \\
\hline 08 & Total Hardness & $\begin{array}{l}\mathrm{mg} / \mathrm{li} \\
\mathrm{t}\end{array}$ & 60.6 & 86.4 & 73.41 & 8.64 & 79.97 & 4.88 & 76.32 & 6.62 & 63.95 & 3.94 \\
\hline 09 & Calcium Hardness & $\begin{array}{l}\mathrm{mg} / \mathrm{li} \\
\mathrm{t}\end{array}$ & 26.9 & 45.3 & 34.64 & 5.097 & 35 & 6.67 & 37.17 & 2.92 & 31.75 & 3.15 \\
\hline 10 & $\begin{array}{l}\text { Magnesium } \\
\text { Hardness }\end{array}$ & $\mathrm{m}_{\mathrm{t}}^{\mathrm{mg} / \mathrm{li}}$ & 28.7 & 54.2 & 38.77 & 7.07 & 44.97 & 5.39 & 39.15 & 5.79 & 32.2 & 2.36 \\
\hline 11 & Calcium- $\left(\mathbf{C a}^{++}\right)$ & $\begin{array}{l}\mathrm{mg} / \mathrm{li} \\
\mathrm{t}\end{array}$ & 10.76 & 18.12 & 13.85 & 2.03 & 14 & 2.67 & 14.87 & 1.16 & 12.7 & 1.26 \\
\hline 12 & Magnesium- $\left(\mathrm{Mg}^{++}\right)$ & $\mathrm{m}_{\mathrm{t}}^{\mathrm{mg} / \mathrm{li}}$ & 6.88 & 13.00 & 9.30 & 1.69 & 10.79 & 1.29 & 9.39 & 1.39 & 7.72 & 0.56 \\
\hline 13 & Dissolved Oxygen & $\begin{array}{l}\mathrm{mg} / \mathrm{li} \\
\mathrm{t}\end{array}$ & 5.9 & 7.4 & 6.74 & 0.40 & 6.3 & 0.25 & 7.175 & 0.19 & 6.75 & 0.11 \\
\hline 14 & Free $\mathrm{CO}_{2}$ & $\begin{array}{l}\mathrm{mg} / \mathrm{li} \\
\mathrm{t}\end{array}$ & 3.5 & 5 & 4.20 & 0.40 & 4.6 & 0.27 & 4.25 & 0.20 & 3.77 & 0.19 \\
\hline 15 & Alkalinity & $\begin{array}{l}\mathrm{mg} / \mathrm{li} \\
\mathrm{t}\end{array}$ & 50.5 & 69.3 & 60.96 & 5.93 & 65.1 & 3.22 & 64.07 & 3.16 & 53.72 & 2.46 \\
\hline 16 & Acidity & $\begin{array}{l}\mathrm{mg} / \mathrm{li} \\
\mathrm{t}\end{array}$ & 2.8 & 4.4 & 3.60 & 0.49 & 4.15 & 0.20 & 3.65 & 0.18 & 3.025 & 0.19 \\
\hline 17 & Phosphate & $\begin{array}{l}\mathrm{mg} / \mathrm{li} \\
\mathrm{t}\end{array}$ & 0.07 & 1.74 & 0.67 & 0.52 & 0.83 & 0.09 & 1.05 & 0.60 & 0.14 & 0.06 \\
\hline 18 & Nitrate & $\mathrm{m}_{\mathrm{t}}^{\mathrm{mg} / \mathrm{li}}$ & 0.16 & 1.11 & 0.58 & 0.33 & 0.30 & 0.12 & 0.93 & 0.17 & 0.52 & 0.31 \\
\hline 19 & Sulphate & $\begin{array}{l}\mathrm{mg} / \mathrm{li} \\
\mathrm{t}\end{array}$ & 16.9 & 23.4 & 19.65 & 2.13 & 19.57 & 1.58 & 21.87 & 1.14 & 17.5 & 0.50 \\
\hline 20 & Chloride & $\mathrm{m}_{\mathrm{t}}^{\mathrm{mg} / \mathrm{li}}$ & 4.3 & 6.9 & 5.61 & 0.77 & 4.67 & 0.33 & 6.02 & 0.35 & 6.15 & 0.47 \\
\hline
\end{tabular}


I J R B A T, Issue (VIII), Vol. I, Jan 2020: 174-185

A Double-Blind Peer Reviewed Journal

Table 3: Monthly and seasonal Physico-chemical readings of Chamorshi Lake during February 2012 to January 2013.

\begin{tabular}{|c|c|c|c|c|c|c|c|c|c|c|c|c|c|c|}
\hline \multirow[t]{2}{*}{ S.N. } & \multirow[t]{2}{*}{ Parameters } & \multirow[t]{2}{*}{ Unit } & \multicolumn{4}{|c|}{ Summer } & \multicolumn{4}{|c|}{ Monsoon } & \multicolumn{4}{|c|}{ Winter } \\
\hline & & & FEB & MAR & APR & MAY & JUN & JUL & AUG & SEP & OCT & NOV & DEC & JAN \\
\hline 01 & Water Temperature & ${ }^{\circ} \mathrm{C}$ & $\begin{array}{l}27.6 \\
5\end{array}$ & 28.85 & $\begin{array}{l}31.0 \\
5\end{array}$ & 32.4 & $\begin{array}{l}30.9 \\
5\end{array}$ & 29.8 & 29 & 29.2 & 29.4 & 27.35 & 24.5 & 25.7 \\
\hline 02 & $\mathbf{P h}$ & $\ldots \ldots \ldots$ & 7.35 & 7.55 & 7.5 & 7.55 & 7.9 & 7.65 & 7.6 & 7.8 & 8.15 & 8.25 & 8.15 & 8.15 \\
\hline 03 & Total Solids & $\mathrm{mg} / \mathrm{lit}$ & $\begin{array}{l}157 . \\
5\end{array}$ & 150 & $\begin{array}{l}154 . \\
5\end{array}$ & 157.5 & 158 & 150.5 & 143 & 139.5 & $\begin{array}{l}135 . \\
5\end{array}$ & 141 & 130 & 125.5 \\
\hline 04 & TDS & $\mathrm{mg} / \mathrm{lit}$ & 137 & 132.5 & 133 & 137.5 & $\begin{array}{l}134 . \\
5\end{array}$ & 133.5 & 123 & 123 & $\begin{array}{l}120 . \\
5\end{array}$ & 125 & $\begin{array}{l}116 . \\
5\end{array}$ & 110 \\
\hline 05 & Suspended Solids & $\mathrm{mg} / \mathrm{lit}$ & 20.5 & 17.5 & 21.5 & 20 & 23.5 & 17 & 20 & 16.5 & 15 & 16 & 13.5 & 15.5 \\
\hline 06 & Turbidity & NTU & 8.95 & 9.25 & 9.5 & 10 & 9.95 & 9.4 & 8.85 & 8.35 & 8 & 8.35 & 8.2 & 8.6 \\
\hline 07 & $\begin{array}{l}\text { Electrical } \\
\text { Conductivity }\end{array}$ & $\begin{array}{l}\mu \mathrm{mhos} / \mathrm{c} \\
\mathrm{m}\end{array}$ & 240 & 248 & 259 & 280 & 273 & 273.5 & 234 & 221 & 199 & 207.5 & 201 & 219 \\
\hline 08 & Total Hardness & $\mathrm{mg} / \mathrm{lit}$ & $\begin{array}{l}272 . \\
5\end{array}$ & 285 & $\begin{array}{l}305 . \\
5\end{array}$ & 294.5 & $\begin{array}{l}254 . \\
5\end{array}$ & 260 & $\begin{array}{l}264 . \\
5\end{array}$ & 255 & 245 & 250 & $\begin{array}{l}252 . \\
5\end{array}$ & 260 \\
\hline 09 & Calcium Hardness & $\mathrm{mg} / \mathrm{lit}$ & $\begin{array}{l}134 . \\
5\end{array}$ & 141 & 153 & 148.5 & $\begin{array}{l}124 . \\
5\end{array}$ & 133.5 & $\begin{array}{l}136 . \\
5\end{array}$ & 129.5 & $\begin{array}{l}110 . \\
5\end{array}$ & 120 & $\begin{array}{l}124 . \\
5\end{array}$ & 124.5 \\
\hline 10 & $\begin{array}{l}\text { Magnesim } \\
\text { Hardness }\end{array}$ & $\mathrm{mg} / \mathrm{lit}$ & 138 & 144 & $\begin{array}{l}152 . \\
5\end{array}$ & 146 & 125 & 126.5 & 128 & 125.5 & $\begin{array}{l}134 . \\
5\end{array}$ & 130 & 128 & 135.5 \\
\hline 11 & Calcium- $\left(\mathbf{C a}^{++}\right)$ & $\mathrm{mg} / \mathrm{lit}$ & 53.8 & 56.4 & 61.2 & 59.4 & 49.8 & 53.4 & 54.6 & 51.8 & 44.2 & 48 & 49.8 & 49.8 \\
\hline 12 & Magnesium-(Mg $\left.{ }^{++}\right)$ & $\mathrm{mg} / \mathrm{lit}$ & $\begin{array}{l}33.1 \\
2\end{array}$ & 34.56 & 36.6 & 35.04 & 30 & 30.36 & $\begin{array}{l}30.7 \\
2\end{array}$ & 30.12 & $\begin{array}{l}32.2 \\
8\end{array}$ & 31.2 & $\begin{array}{l}30.7 \\
2\end{array}$ & 32.52 \\
\hline 13 & Dissolved Oxygen & $\mathrm{mg} / \mathrm{lit}$ & 4.9 & 4.75 & 4.6 & 4.5 & 4.6 & 5.05 & 5.1 & 5.35 & 5.15 & 5.2 & 5.15 & 5.05 \\
\hline 14 & Free $\mathrm{CO}_{2}$ & $\mathrm{mg} / \mathrm{lit}$ & $\begin{array}{l}16.9 \\
5\end{array}$ & 18.15 & 20.1 & 21.5 & 24.1 & 20 & $\begin{array}{l}16.6 \\
5\end{array}$ & 14.8 & $\begin{array}{l}11.2 \\
5\end{array}$ & 10.5 & $\begin{array}{l}10.2 \\
5\end{array}$ & 10.35 \\
\hline 15 & Alkalinity & $\mathrm{mg} / \mathrm{lit}$ & $\begin{array}{l}137 . \\
5\end{array}$ & 143 & 148 & 145 & 150 & 147 & 134 & 127.5 & 123 & 106.5 & 111 & 121 \\
\hline 16 & Acidity & $\mathrm{mg} / \mathrm{lit}$ & 8.95 & 8.55 & 7.9 & 7.5 & 7.1 & 7.55 & 8.35 & 8.05 & 8.8 & 9.3 & 9.5 & 9.1 \\
\hline 17 & Phosphate & $\mathrm{mg} /$ lit & 2 & 2.25 & 2.45 & 2.95 & 3.5 & 3.4 & 2.9 & 2.3 & 1.35 & 0.62 & 0.1 & 0.115 \\
\hline 18 & Nitrate & $\mathrm{mg} /$ lit & 0.31 & 0.37 & 0.43 & 0.70 & 0.94 & 1.10 & 1.22 & 1.41 & 1.05 & 0.55 & 0.31 & 0.2 \\
\hline 19 & Sulphate & $\mathrm{mg} / \mathrm{lit}$ & 35.1 & 38.6 & $\begin{array}{l}40.5 \\
5\end{array}$ & 43.45 & 42.3 & 41.7 & 40.6 & 39.6 & $\begin{array}{l}33.1 \\
5\end{array}$ & 30.6 & $\begin{array}{l}31.5 \\
5\end{array}$ & 33.6 \\
\hline 20 & Chloride & $\mathrm{mg} / \mathrm{lit}$ & 8.05 & 7.1 & 6.75 & 6.4 & 7.15 & 7.55 & 7.95 & 8.8 & 9.6 & 10 & 9.45 & 9.45 \\
\hline
\end{tabular}


I J R B A T, Issue (VIII), Vol. I, Jan 2020: 174-185

A Double-Blind Peer Reviewed Journal
OPEN

Table 4: Monthly and seasonal Physico-chemical readings of Chamorshi Lake during February 2013 to January 2014

\begin{tabular}{|c|c|c|c|c|c|c|c|c|c|c|c|c|}
\hline S.N & Parameters & Unit & Annual & Annual & Annual & Annual & $\begin{array}{l}\text { Summe } \\
\mathbf{r}\end{array}$ & $\begin{array}{l}\text { Summe } \\
\mathbf{r}\end{array}$ & $\begin{array}{l}\text { Monsoo } \\
\mathrm{n}\end{array}$ & $\begin{array}{l}\text { Monsoo } \\
\mathrm{n}\end{array}$ & Winter & Winter \\
\hline & & & Min & $\operatorname{Max}$ & Avg. & $\mathrm{SD}$ & Avg. & SD & Avg. & SD & Avg. & SD \\
\hline 01 & Water Temperature & ${ }^{\circ} \mathrm{C}$ & 24.5 & 32.4 & 28.82 & 2.15 & 29.98 & 1.85 & 29.73 & 0.75 & 26.73 & 1.84 \\
\hline 02 & pH & $\ldots \ldots \ldots$ & 7.35 & 8.25 & 7.8 & 0.29 & 7.48 & 0.08 & 7.73 & 0.11 & 8.17 & 0.04 \\
\hline 03 & Total Solids & $\mathrm{mg} / \mathrm{lit}$ & 125.5 & 158 & 145.20 & 10.69 & 154.87 & 3.06 & 147.75 & 7.12 & 133 & 5.82 \\
\hline 04 & TDS & $\mathrm{mg} / \mathrm{lit}$ & 110 & 137.5 & 127.16 & 8.42 & 135 & 2.26 & 128.5 & 5.51 & 118 & 5.51 \\
\hline 05 & Suspended Solids & $\mathrm{mg} / \mathrm{lit}$ & 13.5 & 23.5 & 18.04 & 2.88 & 19.87 & 1.47 & 19.25 & 2.79 & 15 & 0.93 \\
\hline 06 & Turbidity & NTU & 8 & 10 & 8.95 & 0.64 & 9.425 & 0.38 & 9.13 & 0.59 & 8.28 & 0.21 \\
\hline 07 & $\begin{array}{l}\text { Electrical } \\
\text { Conductivity }\end{array}$ & $\begin{array}{l}\mu \mathrm{mhos} / \mathrm{c} \\
\mathrm{m}\end{array}$ & 199 & 280 & 237.91 & 27.80 & 256.75 & 15.02 & 250.37 & 23.33 & 206.62 & 7.80 \\
\hline 08 & Total Hardness & $\mathrm{mg} / \mathrm{lit}$ & 245 & 305.5 & 266.58 & 18.20 & 289.37 & 12.14 & 258.5 & 4.07 & 251.87 & 5.41 \\
\hline 09 & Calcium Hardness & $\mathrm{mg} / \mathrm{lit}$ & 110.5 & 153 & 131.70 & 11.55 & 144.25 & 7.07 & 131 & 4.5 & 119.87 & 5.71 \\
\hline 10 & Magnesium Hardness & $\mathrm{mg} / \mathrm{lit}$ & 125 & 152.5 & 134.45 & 8.65 & 145.12 & 5.17 & 126.25 & 1.14 & 132 & 3.10 \\
\hline 11 & Calcium- $\left(\mathrm{Ca}^{++}\right)$ & $\mathrm{mg} / \mathrm{lit}$ & 44.2 & 61.2 & 52.68 & 4.62 & $\mathbf{5 7 . 7}$ & 2.83 & 52.4 & 1.8 & 47.95 & 2.28 \\
\hline 12 & Magnesium-( $\left.\mathrm{Mg}^{++}\right)$ & $\mathrm{mg} / \mathrm{lit}$ & 30 & 36.6 & 32.27 & 2.07 & 34.83 & 1.24 & 30.3 & 0.27 & 31.68 & 0.74 \\
\hline 13 & Dissolved Oxygen & $\mathrm{mg} / \mathrm{lit}$ & 4.5 & 5.35 & 4.95 & 0.26 & 4.68 & 0.15 & 5.025 & 0.27 & 5.13 & 0.05 \\
\hline 14 & Free $\mathrm{CO}_{2}$ & $\mathrm{mg} /$ lit & 10.25 & 24.1 & 16.21 & 4.59 & 19.17 & 1.75 & 18.88 & 3.53 & 10.58 & 0.39 \\
\hline 15 & Alkalinity & $\mathrm{mg} / \mathrm{lit}$ & 106.5 & 150 & 132.79 & 14.24 & 143.37 & 3.83 & 139.62 & 9.22 & 115.37 & 6.84 \\
\hline 16 & Acidity & $\mathrm{mg} /$ lit & 7.1 & 9.5 & 8.38 & 0.74 & 8.22 & 0.56 & 7.76 & 0.47 & 9.17 & 0.25 \\
\hline 17 & Phosphate & $\mathrm{mg} / \mathrm{lit}$ & 0.1 & 3.5 & 1.99 & 1.14 & 2.41 & 0.34 & 3.025 & 0.47 & 0.54 & 0.50 \\
\hline 18 & Nitrate & $\mathrm{mg} / \mathrm{lit}$ & 0.2 & 1.41 & 0.71 & 0.39 & 0.45 & 0.14 & 1.17 & 0.16 & 0.53 & 0.32 \\
\hline 19 & Sulphate & $\mathrm{mg} /$ lit & 30.6 & 43.45 & 37.56 & 4.31 & 39.42 & 3.03 & 41.05 & 1.03 & 32.22 & 1.20 \\
\hline 20 & Chloride & $\mathrm{mg} / \mathrm{lit}$ & 6.4 & 10 & 8.18 & 1.18 & 7.07 & 0.61 & 7.86 & 0.61 & 9.62 & 0.22 \\
\hline
\end{tabular}

